\title{
Barnehager og høytidsmarkering En gjennomgang og diskusjon av begrunnelser knyttet til manglende markering av ikke-kristne høytider
}

\author{
Av Audun Toft og Kristine Toft Rosland
}

This article is based on a 2010/2011 survey on religious festivals in kindergartens in the Norwegian region Helgeland. We discovered that only holidays of Christian origin were marked, despite it being a curricular requirement that kindergartens mark festivals from all religions represented among the children. In this article, we examine and discuss the reasons given. We find that kindergarten teachers are uneasy marking non-Christian festivals. In addition, they also claim that some parents of kindergarteners do not want their festivals marked. We apply migration theory in the discussion, and conclude that not marking the festivals of children from religious minorities is unfortunate for both minority and majority children. Minority children lose opportunities of positive identification and recognition. Majority children are precluded from learning about other religious festivals than their own and thereby from expanding their cultural repertoire. We also find that parent involvement is a key factor in succeeding in this area, as one of the main obstacles for our informants is the lack of personal relationship to the festivals. They lack the personal resources to give the children an authentic experience when it comes to non-Christian festivals.

Audun ToFt f. 1977. Høgskolelektor Høgskolen i Nesna.8700 Nesna.E-post:audunt@hinesna.no

Kristine TofT RosLand f. 1975, Stipendiat Teologisk fakultet, Universitetet i Oslo, Postboks 1023 Blindern 0315 Oslo.E-post: k.t.rosland@teologi.uio.no

\section{INNLEDNING}

I en undersøkelse fra 2010/11 fant vi at ingen av barnehagene vi undersøkte markerte ikkekristne høytider. Dette på tross av at de hadde barn med tilhørighet til andre religioner enn kristendommen, og at Rammeplanen for barnehagens innhold og oppgaver ( $\mathrm{KD}$ 2011) pålegger barnehagene å gjøre dette. I denne artikkelen ønsker vi å se nærmere på barnehagepersonalets begrunnelser for denne praksisen.

Barnehagene vi undersøkte hadde $\mathrm{i}$ all hovedsak barn fra familier med kort botid i Norge. De kom fra asylmottak eller fra nylig bosatte familier. Dette gir barnehagene noen spesielle utfordringer, og vi mener det er relevant å trekke inn perspektiver fra migrasjonsforskning når vi ser nærmere på noen av grunnene personalet oppgir.

I artikkelen vil vi bruke mye plass på empirien. Vi vil så drøfte nærmere de begrunnelsene vi mener har størst betydning med tanke på å få endret praksis så det legges til rette for å ivareta Rammeplanens krav.

\section{Lovverk om høytidsmarkering}

I de aller fleste barnehager i Norge går det barn fra språklige, etniske eller religiøse minoriteter. Det føres ingen statistikk over religiøse minoriteter $\mathrm{i}$ barnehagene, men når vi vet at $13,2 \%$ av barna i norske barnehager i 2013 
var minoritets-språklige ${ }^{1}$, kan vi på bakgrunn av dette fastslå at mange barnehagebarn også tilhører andre religioner og trossamfunn enn Den norske kirke (www.ssb.no ${ }^{2}$ ). Rammeplan for barnehagens innhold og oppgaver legger klare føringer for hvordan barnehagene skal forholde seg til minoritetsbarna og deres kulturbakgrunn.

Barn som tilhører den samiske urbefolkningen, de nasjonale minoritetene og barn fra etniske minoritetskulturer, må få støtte til å utvikle sin dobletilhørighet.Barns møtemed ulikekulturer og tradisjoner legger grunnlaget for respektfull samhandling mellom ulike etniske grupper. Bevissthet om egen kulturarv og delaktighet $i$ andres kultur skal bidra til at barn kan sette seg inn $i$ andres ståsted (KD 2011: 36).

Dette er ikke tenkt som tiltak som kun skal berike minoritetsbarna. Rammeplanen fastholder at det å møte ukjent kultur også er utviklende for majoritetsbarna.

Et mote med noe som er forskjellig fra ens eget, gir muligheter for å utvikle en positiv nysgjerrighet overfor menneskers og kulturers likheter og ulikheter (KD 2011: 23).

Det er i lys av dette Rammeplanens krav om høytidsmarkering må leses.

Barnehagen skal bidra til at barna:

får kjennskap til kristne hoytider og tradisjoner og tradisjoner knyttet til høy-tider $i$ religioner og livssyn som er representert $i$ barnegruppen
Personalet må:

la den kristne kulturarven komme til uttrykk blant annet gjennom høytidsmarkeringer og markere andre religiøse, livssynsmessige og kulturelle tradisjoner som er representert $i$ barnehagen (KD 20011: 47 vår utheving) ${ }^{3}$

\section{Tidligere forskning}

Kombinasjonen av en juridisk bindende rammeplan som gjelder for både offentlige og private barnehager, og kravet om høytidsmarkering for alle livssyn representert i barnehagen, skaper en særnorsk situasjon på dette området. Barnehageforskning er et område i vekst i Norge, men det er fortsatt kunnskapshull. En kunnskapsoversikt over forskning på kvalitet og innhold i norske barnehager setter det litt på spissen ved å betegne situasjonen slik: «[E]t forskningsfelt med mange interesserte og interessante aktører, men foreløpig relativt få forskere som produserer studier med høy vitenskapelig kvalitet» (Borg, Kristiansen og Backe-Hansen 2008: 21). Endringer i rammeplan, formålsparagraf og en ny flerkulturell virkelighet gjør at tilfanget av direkte relevant tidligere forskning er begrenset. En svært viktig studie om rammeplan og praksis i barnehagen er evalueringen av innføringen av Rammeplanen 2006, Alle teller mer (Østrem et al. 2009). Denne studien viser at fagområdet «Etikk, religion og filosofi», som høytidsmarkeringskravene ligger inn under, er det fagområdet det arbeides minst med i barnehagene. Dette er også ettav defagområdene som oppleves som mest krevende. Også andre områder som oppleves som vanskelige, prioriteres lavt. Mye tyder på at flerkulturelle

1 Barn med svensk, dansk eller engelsk som morsmål regnes ikke med blant disse.

2 Om ssb: Tallene genereres ved å legge inn variabler i tabellen «Antallet minoritetsspråklige barn i barnehage i forhold til antallet barn med barnehageplass ». Enhet: «Prosent», «Landet» og «2013» (http://www.ssb.no/tabell/04903)

3 Rammeplanen ble revidert i 2011, og vi bruker her formuleringene fra gjeldende plan. På undersøkelsestidspunktet var ikke disse endringene kommet. Pålegget om å markere høytider i religioner og livssyn som er representert i barnehagen endret seg ikke med revisjonen selv om formuleringene ble noe endret. 
perspektiver generelt er nedprioritert. Selv innenfor det fagområdet som det arbeides mest med, «Kommunikasjon, språk og tekst», er det bare $10 \%$ av de barnehagene som har jobbet mye med fagområdet, som har lest tekster fra andre kulturer. Dette tyder på at det kan være en forskjell i hvordan majoritets- og minoritetskultur synliggjøres i barnehagene.

Det er utgitt noen empiriske studier som berører høytidsmarkeringer (bl.a. Sagberg 2001, Sødal 2000 og Winje 2008). De to siste er i stor grad didaktisk rettet. Geir Winje har i tillegg skrevet en ressursbok for høytidsmarkering i barnehage. I denne legger han vekt på at høytidsmarkeringer i barnehagen ikke skal begrunnes ut ifra religion, men at de er pedagogiske aktiviteter, med todelt hensikt

1) Noen barn skal få oppleve bekreftelse og lære om egen religion og kultur,

2) Andre barn skal oppøve respekt og lære om andres religion (Winje 2010: 7).

Hvis bare de kristne høytidene markeres, er det bare barn med kristen kulturbakgrunn som får bekreftelse og kunnskap om egen religion og kultur, mens alle andre barn oppøves i respekt. Skal alle barn i barnehagen nås av begge disse målene, må også minoritetsbarnas høytider markeres.

Ragnhild Fauske har undersøkt bruken av religiøse fortellinger i barnehager i Møre og Romsdal. De aller fleste barnehagene brukte kristne religiøse fortellinger. Kun 1 $\%$ av barnehagene i undersøkelsen brukte fortellinger fra islam, mens $14 \%$ av barnehagene hadde barn med muslimsk bakgrunn. De religiøse fortellingene ble i stor grad brukt i forbindelse med høytider (Fauske 2012). Fauskes undersøkelse støtter dermed opp under inntrykket fra Alle teller mer, minoritetsog majoritetskultur synliggjøres ulikt. Kristne fortellinger brukes, andre religioners fortellinger brukes ikke. Vår undersøkelse (Rosland og Toft 2013) underbygger dette. Kristne høytider markeres, i motsetning til andre religioners høytider. Det kan se ut som om hovedproblemet når det gjelder høytidsmarkeringer ikke først og fremst er at fagområdet ERF er nedprioritert, for kristne høytider markeres, og kristne fortellinger brukes, men at minoritetsbarns kultur ikke er gitt plass. Dermed får de ikke «støtte i å utvikle sin doble kulturtilhørighet», og majoritetsbarn får ikke hjelp til å «sette seg inn i andres ståsted» (KD 2011: 21). En stor studie av flerkulturelle barnehager utenfor storbyene, Den flerkulturelle barnehagen i rurale områder, viser at personalet i de undersøkte barnehagene samarbeidet sjelden (56\%) eller aldri (11,5 $\%)$ med foreldrene til de minoritetsspråklige barna om markering av høytider og merkedager (Andersen et al. 2011).

\section{Om undersøkelsen}

Empirien i artikkelen er hentet fra en undersøkelse om høytidsmarkeringer i barnehager i fire kommuner på Helgeland. Undersøkelsen var todelt. I første del ble det sendt spørreskjemaer til alle barnehagene i de utvalgte kommunene. Spørreskjemaet hadde fokus på hvordan ulike høytider ble markert. I undersøkelsens andre del valgte vi ut to barnehager der styrer, en pedagogisk leder på småbarnsavdeling og en pedagogisk leder på storbarnsavdeling ble intervjuet i hver av barnehagene $e^{4}$.

Det kom frem i spørreskjemaene at ingen av barnehagene som svarte, markerte ikkekristne høytider, selv om flere av dem hadde

4 I denne artikkelen kaller vi styrerne for Grete (barnehage 1) og Kari (barnehage 2). De pedagogiske lederne er Ingeborg (småbarnsavdeling, barnehage 1), Elin (storbarn, barnehage 1), Miriam (småbarn, barnehage 1) og Stine (storbarn, barnehage 2). 
andre religioner representert i barnegruppen. Dette la noen føringer for valget av barnehager til undersøkelsens andre del. Vi gjorde et strategisk utvalg på bakgrunn av størrelse og erfaring med en flerkulturell barnegruppe. Begge de valgte barnehagene har tatt imot barn fra kommunenes asylmottak. Felles for begge er at de derfor også har hatt rask utskifting i barnegruppens sammensetting. Hva slags bakgrunn asylsøkere og flyktninger har, veksler med både globale og nasjonale hendelser, og barnehagene i vår undersøkelse har derfor hatt en rekke minoritetskulturer representert over mange år, men sjelden samme gruppe over lengre tid.

Intervjuene bygget på en halvstrukturert intervjuguide. Spørsmålsstrukturen var den samme i alle intervjuene, men med stor plass til oppfølgingsspørsmål. Med bakgrunn i svarene fra spørreundersøkelsen legger intervjuguiden stor vekt på markering av muslimske høytider. Vi har i en tidligere artikkel sett nærmere på barnehagenes kjennskap og holdning til Rammeplanens krav. Det viste seg at de ansatte både hadde et ønske om å markere disse høytidene, og at de var klar over at de ikke fulgte Rammeplanen på dette punktet (Rosland og Toft 2013). I denne artikkelen vil vi se nærmere på de konkrete grunnene personalet oppgir 5 .

\section{Analyse}

I analysearbeidet til denne artikkelen har vi i all hovedsak arbeidet menings-kategoriserende (Kvale 2001: 129). Vi har analysert intervjuene og kategorisert svarene etter hvilke motiver som går igjen hos informantene når det kommer til markering av muslimske høytider. I hovedsak har vi to hovedkategorier: a) personalets forutsetninger og b) foreldrene. Under disse isolerer vi syv kategorier: i) manglende kunnskap om religioner/høytider, ii) manglende kompetanse på arbeidsformen, iii) manglende personlig forhold til høytidene, iv) manglende ønsker fra foreldrene, v) engstelse for å støte foreldrene, vi) manglende ressurser og vii) manglende ressurspersoner $i$ narmiljøet.

Med utgangspunkt i disse kategoriene drøfter vi empirien nærmere med tanke på å legge til rette for endret praksis.

\section{EMPIRI}

Alle informantene fikk spørsmål om hvordan de forholdt seg til muslimske høytider. Grunnene de oppga var veldig like. De fleste elementene i begrunnelsene gikk igjen selv om informantene jobbet i forskjellige avdelinger i forskjellige barnehager. I gjennomgangen av empirien vil vi derfor ikke i særlig grad skille mellom barnehagene.

Intervjuer: Hvordan gjør dere da i forbindelse med muslimske høytider?

Elin: Ja, det er jo noe vi har diskutert tusen ganger. Og vi har aldri egentlig helt greid å finne ut hva vi skal gjøre og ikke gjøre. For det føles litt kunstig det at vi som vet minst om det på en måte skal lage til noe for noen ... vi er kanskje litt redd for at det skal bli feil. Noen ganger så har vi spurt foreldrene, altså vi bruker å spørre de som vi har på storavdelingen om de ønsker at vi skal markere det på noe vis. Men de vil ofte ikke det, for ungene er ikke her engang. De er hjemme. På de dagene.

Alle informantene våre utrykker usikkerhet når vi snakker om markering av høytider knyttet til islam (og andre religioner). Denne usikkerheten er omfattende og gjelder flere

5 Mer informasjon om selve undersøkelsen er gitt ut i en tidligere artikkel (Rosland og Toft 2013). 
forhold. Personalet føler de har for lite kunnskap om islam, og at det er vanskelig å gjøre noe ut av høytider de ikke har noe personlig forhold til. De synes heller ikke at de har gode arbeidsmetoder og opplegg. I tillegg uttrykker flere at de er usikre på hvordan foreldrene vil reagere på at barnehagen markerer «deres» høytider. De er vare for at de kan komme til å «trø noen på føttene», som Stine sier det.

\section{Personalets forutsetninger for å markere}

Mangel på kunnskap og kompetanse om andre religioner trekkes frem av alle de pedagogiske lederne i denne forbindelsen. På spørsmål om religion i barnehagen svarer Miriam:

Nå er ikke jeg rette personen til å snakke om de forskjellige religionene, for jeg vet altfor lite. [...] da må det vere noen kompetente voksne som vet hva religionen går ut på. Altså man vet jo litt, men jeg vet fryktelig lite. Ja, det må jeg bare innrømme.

Samme tanker finner vi hos alle de pedagogiske lederne. «Jeg kan jo selvsagt lese meg opp, men jeg føler meg ikke helt sånn der at jeg kan nok egentlig», sier Elin. Stine fremhever også flere steder at hun mangler kunnskap om islam, som for eksempel når hun sier at «jeg kan jo ikke Muhammed sin historie, for å kunne fortelle den på samme måte som jeg kan fortelle om Jesu historie». Ingeborg slår fast at «det går nok en del på kunnskap, rett og slett».

En løsning flere peker på ville være å ha gode opplegg og ressurser laget av andre som man kunne trekke inn. Men personalet i barnehagene viser til at dette ikke er lett tilgjengelig. De mangler konkrete arbeidsmetoder og forslag til opplegg. Elin går nokså langt i å hevde at dette er en stor svakhet i lovverket. På spørsmål om hva hun tenker om at lovverket er såpass tydelig på at de skal markere høytider knyttet til tradisjoner de har representert i barnehagen, sier hun.

Da tenker jeg at når de gjør det så synes jeg at da får de jammen også komme med en god forklaring på hvordan man skal gjøre det. For jeg tror at det er utrolig mye usikkerhet ute og går når det gjelder akkurat disse tingene. [...] Ja, gi oss noen gode måter å gjøre det på. Noen redskap, liksom.

Også de andre pedagogiske lederne uttrykker at gode opplegg og ressurser hadde vært en god hjelp. De etterlyser konkrete arbeidsmetoder og ressurser der de kan finne forslag til måter å markere høytider på.

På bakgrunn av det som kommer frem i intervjuene, vil kunnskap og opplegg alene neppe endre situasjonen. Det er nemlig et annet perspektiv som vektlegges sterkt. Det er problematisk å skulle markere høytider man ikke har noe personlig forhold til. Markering av de kristne høytidene kommer naturlig i barnehagene. Disse har personalet et forhold til, selv om de ikke nødvendigvis har så mye kunnskap om innholdet i de kristne høytidene heller. Når Elin ikke kan nok om muslimske høytider, opplever hun det som vanskelig å lese seg opp. Mens når hun forteller om påskemarkeringen, der hun også opplever at hun har for lite kunnskap, sier hun: «Så jeg må lese meg opp hver gang». Manglende kunnskap oppleves som mindre problematisk når det gjelder en høytid man har et forhold til. Om muslimske høytider utdyper hun: «For jeg synes at det føles ikke ... Det er ikke min tradisjon. Det er vanskelig å på en måte å skulle lære andre noe som jeg ikke har noe særlig forhold til selv.»

Disse tankene går igjen $\mathrm{i}$ de andre intervjuene, som når Stine sier: «Når man ikke 
er muslim selv, så tenker jeg at det er litt rart å skulle feire noe man på en måte ikke har noe ... eller vet hvordan. Altså hvordan man gjør det, eller hva de på en måte føler.» Markering av muslimske høytider blir særlig problematisk fordi det ikke blir en ekte fremstilling. Informantene opplever ikke eierskap til høytidene, og spør seg om hvordan de da kan lage opplegg knyttet til dem.

\section{Foreldrene}

Her kommer en annen side av usikkerheten frem. Dette dreier seg jo om minoritetenes høytider. Foreldrene er de som har det personlige forholdet til høytidene. Hva hvis man gjør noe feil? Hvordan vil det oppfattes av foreldrene?

Elin: Jeg tror det er mye derfor man vegrer seg. For man vet ikke helt hva man skal gjøre. Man er redd for å støte dem. Man er redd for å forncerme dem på noe vis i forhold til dette. Altså, man vil jo ikke gjøre noe som er stort og bra for dem til noe [som er negativt] $]^{6}$.

Denne varheten for å støte noen blir sett sammen med respekt for foreldrene. Barnehagen skal forholde seg til foreldrenes ønsker. Det er foreldrene som har mandatet til å oppdra egne barn, særlig til å bestemme barnas religiøse oppdragelse ${ }^{7}$. I begge barnehagene har de noe bevissthet rundt at de burde ha markert høytider knyttet til blant annet islam, siden de har barn med muslimsk bakgrunn. Men de mener at dette noen ganger er i strid med foreldrenes ønsker. Dette er erfaringer de har gjort i begge barnehagene. Det er særlig styrerne som fremhever dette poenget.
Grete, som er styrer i barnehage 1, legger sterk vekt på respekten for foreldrenes ønsker. Hun viser til at det er litt ulike meninger blant foreldrene, men kommer stadig tilbake til at mange foreldre med muslimsk bakgrunn ikke ønsker høytidsmarkering i barnehagen.

Ja, vi har snakket litt med foreldre om det, men de er jo veldig delt $i$ synet på det. Det er ikke noen som har hatt noe tydelig ønske om at vi skal markere så mye, det er det ikke. [...]

Også er vi jo veldig usikre, for jeg tror ikke alle familiene som vi har i barnehagen kanskje vil markere sin egen religion heller. Vi har jo hatt unger her, eller foreldre her, som på en måte har lagt til side alt $i$ sin gamle kultur og som helst vil vere bare norske også. [...] Så selv om vi har prøvd å spørre litt om kultur, og spurt om de vil det og det. Så, nei, min gutt, han skal vere norsk, har vi fätt til svar. Og da må vi jo respektere det, synes jeg.

Hun peker også på dette med at de er redd for å støte foreldrene. Spesielt da de foreldrene som ønsker at barna skal bli norske i barnehagen. Hun knytter dette til det at de har reist vekk fra eget hjemland. På spørsmål om hva hun tenker på når hun sier hun er redd for å støte noen så svarer hun: «Ja, altså da tenker jeg på de foreldrene som kanskje ikke er så glade i sin egen kultur lenger.»

Styrer i den andre barnehagen er enda tydeligere på flertallet av foreldrene overhodet ikke ønsker dette.

Intervjuer: Gjør dere noe i forbindelse med a markere andre religioners høytider?

\footnotetext{
6 Informanten slutter setningen åpent, men meningen er tydelig i sammenhengen. Hun ønsker ikke gjøre noe som er fint for foreldrene og barna til noe negativt fordi hun ikke kan nok om dette.

7 Dette mandatet er nedfelt i lovverket flere steder, også i menneskerettighetene (For eksempel i Den europeiske menneskerettskonvensjonen, protokoll 1, artikkel 2.)
} 
Kari: Ja, det kunne vi jo veldig gjerne gjort, men det vi opplever for det meste, det er at de som har en annen type religion, som vi har hatt her $i$ barnehagen, ikke ønsker at det skal vere $i$ barnehagen. Det ønsker de å ha hjemme i sine egne omgivelser. Og de vil at barna skal ha det norske i barnehagen. Det er det vi opplever for det aller meste.

Denne tanken om at barnehagen skal være et sted der barna opplever det norske, mens eventuell feiring gjøres hjemme, trekker styrer frem flere steder i intervjuet. Hun sier også at det kan være litt ulikt. «Nå er det jo litt forskjellig fra familie til familie. Men jeg har inntrykk av at de samler seg om at sånn vil det være.»

De pedagogiske lederne nevner mye av det samme, selv om det er litt forskjell på tvers av barnehagene. I barnehage 1 har de diskutert temaet mange ganger i personalgruppa. De er klar over at de ikke gjør det de skal på dette punktet. Elin sier hun også har snakket med foreldrene om dette noen ganger. «... om de ønsker at vi skal markere det på noe vis. Men de vil ofte ikke det, for at de ungene er ikke her engang. De er hjemme på de dagene.» Ingeborg peker på at hun har veldig små barn på sin avdeling, og at markering i liten grad har plass der. Men også hun trekker frem foreldre når hun resonnerer litt rundt grunnen til at det ikke markeres muslimske høytider. «Jeg tror jo at folk synes det er vanskelig, at de er usikre på hvordan de skulle markert det, og jeg tror de er usikre på hva foreldrene forventer også, på en måte. At den dialogen kanskje ikke er god nok.»

I den andre barnehagen fortelles det at de har hørt fra styrer at foreldrene ikke ønsker å markere høytider knyttet til islam. Miriam resonnerer videre med at i så fall er dette noe barnehagen må respektere. Men hun trekker frem at dette har hun faktisk ikke selv tatt initiativ til å spørre om. Når hun reflekterer litt videre rundt dette, sier hun at:

Jeg synes jo det er rart hvis de ikke er positive til det. For det ville jo jeg tenkt selv hvis jeg hadde vert $i$ et annet land, så hadde jeg synes det hadde vert hyggelig hvis de hadde gjort noe med våre hoytider $i$ skole eller barnehage til mine barn.

Stine har heller ikke hatt dialog om dette med foreldre, men sier at hun opplever at noen vil ha høytidene sine for seg selv.

Barnehagene opplever altså at noen foreldre aktivt sier at de ikke ønsker markering av egne høytider i barnehagen, men synet på om dette er representativt for alle foreldrene, er mer delt. Kari trekker også inn et annet perspektiv. «Jeg tenker jo noen ganger at når foreldrene ikke ønsker det, så tenker jeg at ok, da har vi i grunn veldig mye å holde på med i alle fall.» Dette er et poeng vi også finner igjen i flere av intervjuene. Barnehagen har mange oppgaver og begrenset med tid og personale. Noen ting må nedprioriteres. Når da foreldrene ikke ønsker at høytidene skal markeres i barnehagen, så vil det være greit å ikke sette inn for mye ressurser på dette punktet.

Det er mulig at intervjusituasjonen påvirker hvordan styrerne trekker frem at motstanden mot å markere i hovedsak er representativ for foreldrene generelt. De blir indirekte bedt om å forsvare seg når det kommer til hvorfor barnehagen ikke følger Rammeplanen. På et annet sted i intervjuet nyanserer Kari bildet noe:

Intervjuer: Og dere tenker også at hvis dere hadde foreslått å gjøre noe, så ville det bli avvist eller?

Kari: Det er jeg ikke så sikker på. Men det er liksom bare blitt sånn. Nei, det er jeg ikke så 
sikker på. Hvis vi sier at nå vil vi gjerne ha en idfest, så tror jeg egentlig de ville stilt opp.

\section{Ressurspersoner}

Hva skal til for at barnehagene skal markere høytider knyttet til islam? Informantene våre trekker frem både mer kunnskap og tilgang til konkrete opplegg som mulige løsninger. Men mest av alt trekkes det frem at man trenger noen med et personlig forhold til de aktuelle høytidene. «Jeg er jo veldig på gyngende grunn, så jeg føler jeg skulle hatt noen som var muslimer som kunne ha tatt det som var positivt å gjøre sammen med ungene», sier Stine. Eller som Elin sier det: «Jeg ville heller ha trukket inn noen, egentlig. For jeg tror det er vanskelig å tilegne seg akkurat denne typen kunnskap. Det med praktisk hvordan driver dere på med de her greiene?»

Her er det også verdt å merke seg at i begge barnehagene har de vært mer aktive tidligere når det kommer til å lage opplegg knyttet til andre kulturer. Dette skyldtes foreldre som selv tok initiativ, samt personer i språkpraksis i barnehagen. I barnehage 2 forteller de at de faktisk lagde mye opplegg rundt muslimske høytider tilbake for tolv år siden da de hadde kurdiske muslimer representert. Disse ressurspersonene bare satte $\mathrm{i}$ gang og hadde flotte markeringer. Men siden barnegruppen endrer seg raskt og ressurspersonene forsvinner, videreførte de ikke dette.

Miriam: Men vi hadde i hvert fall to mannfolk $i$ barnehagen som jobbet her. Og da feiret vi masse. Og det var jo de som hadde med damene sine som satt på kjøkkenet og laget mat og feiret det her, hoytidene deres. Men etter at de dro herfra, så...

I barnehage 1 forteller de også at de hadde foreldre som var aktive og selv kom og spurte om de kunne lage mat og vise bilder knyttet til familiens kultur. To personer i språkpraksis bidro sterkt til å synliggjøre disse andre kulturene. Også her forsvant dette med ressurspersonene.

Vi ser altså at i begge barnehagene er det avgjørende for personalet å ha noen med seg som har et forhold til høytidene og som kan bidra. I begge barnehagene finner vi også tanken om at hvis noen av foreldrene aktivt ønsker å dra i gang noe, da vil barnehagen gjerne være med. Det som oftest trekkes frem er at når foreldrene har blitt spurt konkret om de ønsker at barnehagen skal gjøre noe, da har de ikke ønsket dette. På denne måten kan barnehagene vise til at det er foreldrene som ikke har grepet tak i dette. Som Grete sier det når vi snakker om synliggjøring av andre kulturer i barnehagen:

$V i$ er $i$ hvert fall veldig åpne for at de skal få vise seg fram hvis de er interessert $i$ det selv. $\AA$ få vist frem litt av sin egen kultur, og hvordan de tenker og jobber, og hva de står for. Hvis det er noen som vil det, så er vi åpne for at de skal få det.

\section{DRØFTING}

Et etablert begrepspar i norske studier av flerkulturelle institusjoner er skillet mellom et problemorientert og et ressursorientert perspektiv (Hauge 2014; Gjervan, Andersen og Bleka 2009). Dette skillet anvendes med tanke på både skole og barnehage, og viser til hvordan institusjonene ser på minoriteters kultur. Ifølge Hauge ser problemorienterte institusjoner på kulturforskjeller som problematiske, gjerne som tegn på hva som minoritetene mangler for å integreres. Slike institusjoner preges av at majoritetene opplever en stor grad av identitetsbekreftelse, men lite perspektivutvidelse, mens minoritetene opplever liten eller ingen identitetsbekreftelse, 
men mye perspektivutvidelse. Ressursorienterte institusjoner ser derimot kulturelt mangfold som normalen og som en ressurs for felles læring. Her vil barna ideelt oppleve både identitetsbekreftelse og perspektivutviding. Etter et problemorientert perspektiv er foreldrene hindringer. Etter et ressursorientert syn er de ressurser (Hauge 2014: 25-30). Dette skillet mellom problem- og ressursorientert perspektiv er veletablert i norsk skole- og barnehageforskning (se for eksempel Gjervan 2008, Sand 2008 og Fandrem 2011), og er også sterkt betont i politiske dokumenter (Gjervan 2006, KD 2007, KD 2011). Otterstad og Andersen (2012) problematiserer det at en ressurstilnærming nokså ukritisk har fått dominere politiske dokumenter som normen for inkluderingsarbeid. De etterlyser blant annet en bredere teoretisk forankring og ønsker at ulike perspektiver på mangfold og inkludering skal tas inn i styringsdokumentene. Dette er en viktig nyansering i forhold til et begrepspar (ressurs-/problemorientert) som lenge har vært enerådende. Vår undersøkelse viser også at dette begrepsparet ikke er dekkende i forhold til å forklare sammenhengen mellom holdning og handling i barnehagene vi undersøkte.

Gjennomgående i våre intervjuer har personalet $i$ begge barnehagene et ressursorientert perspektiv slik dette beskrives i faglitteraturen. De anerkjenner at når det kommer til egen kultur, er foreldrene uvurderlige ressurser, og at denne kompetansen er ønskelig i barnehagen. Men av ulike grunner klarer ikke barnehagene å trekke på disse ressursene. På det feltet vi så på, høytidsmarkering, begrunnes dette med foreldrenes egne ønsker, eventuelt manglende initiativ når de blir spurt om de ønsker markering av egne høytider i barnehagen. I praksis blir dermed disse barnehagene preget av de samme tingene som kjennetegner problemorienterte barnehager, selv om personalet både anerkjenner foreldrenes kompetanse og ser på dem som viktige ressurser. Det at de selv mangler de nødvendige ressursene for å markere høytidene på en god måte, vektlegges som vi har sett av alle vi har snakket med.

I den tidligere nevnte undersøkelsen Den flerkulturelle barnehagen $i$ rurale områder oppsummeres funnene knyttet til synliggjøringen av minoritetskulturer i barnehagen slik:

Undersøkelsen viser eksempelvis at det er den norske/lokale kulturen som $i$ stor grad velges av pedagogiske ledere som utgangspunkt for samspill $i$ mindre og større grupper. Samspill ut fra temaer som hverdagsliv, sanger, regler, eventyr, religiøse tradisjoner m.m. [...] velges av svert mange med utgangspunkt $i$ norsk/ lokal kultur, og av svert få med utgangspunkt $i$ minoritetskulturer i norsk sammenheng. Imidlertid uttrykker en stor andel av pedagogiske ledere at det er viktig å formidle minoritetskulturer i barnegruppene. Slik kan det se ut til at det er meget stor forskjell på holdning og handling (Andersen et al. 2011:118-119).

\section{Manglende tilknytning til muslimske høytider}

Hvis det nå er sånn at barnehagene har et ressursorientert perspektiv, hvorfor omsettes det ikke til praksis? Vi mener at noe av svaret ligger i den manglende personlige tilknytningen til stoffet. I boken Autensitet og undring undersøker Sturla Sagberg kristendommens plass i norske barnehager. Særlig vekt legger han på markering av kristne høytider i barnehagene. Denne boken bygger på empiri fra en tid tilbake ${ }^{8}$, og

8 Boken er fra 2001, empirien fra 1995. Den første rammeplanen for norsk barnehage ble innført fra 1996. 
fokuset på kristendommens plass i barnehagen blir litt på siden av vår problemstilling. Derimot er hans teoretiske perspektiv knyttet til autentisitetsbegrepet relevant for oss. Sagberg bruker det han kaller autentisitetsidealet som «et hermeneutisk innsteg [...] på bakgrunn av den betydningen mine informanter har lagt i det å ha et ekte forhold til kristendommen i sin formidling» (Sagberg 2001:329). Denne ektheten er ikke helt presist definert, men kan vektlegges subjektivt, personen som formidler har selv et personlig forhold til stoffet, eller objektivt, barna må møte noe som er ekte. Felles i Sagbergs store intervjumateriale er i alle fall tanken om at formidlingen av kristne høytider motiveres av et ideal om autentisitet. Han skriver:

Idealet om å formidle kristendom som noe ekte og helhetlig er heller ikke knyttet entydig til at formidleren har en bevisst kristen tro. Derimot er det naer sammenheng mellom et slikt ideal og en virkelighetsforståelse der gudstro og Jesustro er plausibelt, enten som barnelardom, aktiv religiøs tro eller element $i$ en kultur (Sagberg 2001: 332).

Sagbergs videre kategoriseringer i forhold til autentisitet er mindre anvendelig for oss, men akkurat dette poenget finner gjenklang i vårt materiale. Selv om både manglende kunnskap om islam og om ulike nasjonale kulturtrekk blir trukket frem som viktige elementer, er det særlig det at personalet mangler et forhold til høytidene, som oppleves som problematisk når informantene utdyper. De muslimske høytidene er ikke tilgjengelige for dem verken som barnelærdom, egen tro eller som kulturelementer. Alle elementene Sagberg identifiserer som viktige motivasjonsfaktorer hos sine informanter, styrt av et sterkt ideal om at det som presenteres skal være ekte, er fraværende for personalet i vår undersøkelse.

Når personalet opplever høytidene knyttet til islam som så lite tilgjengelige, og de samtidig er usikre på foreldrenes reaksjon, blir argumentet om at foreldre ikke vil ha en slik markering enda sterkere. Dersom foreldrene ikke ønsker det, vil det da i det hele tatt være rett av barnehagen å sette i gang med høytidsmarkering? Vi finner det nødvendig å gå litt dypere inn i dette spørsmålet.

\section{Foreldrenes ønsker og situasjon}

Det ligger en pliktkollisjon mellom Rammeplanens påbud om høytidsmarkering og foreldrenes ønsker, i alle fall som de oppfattes og formidles av våre informanter. For å kunne diskutere dette fruktbart er det noen ting vi vil se nærmere på. Den ene siden vi ønsker å problematisere, er om de aktive foreldrenes ønsker er representative for minoritetsforeldrene. Her er det en del faktorer knyttet til selve migrasjonsprosessen disse familiene er i, som vil være relevante. Den andre siden vi vil se på, er muligens mer kontroversiell. Er det til barnas beste at barnehagene velger bort markering av minoriteters høytider? Vi har verken ønske om, eller mulighet til, å polemisere mot foreldrenes ønsker. Det vi vil gjøre, er å trekke frem noen elementer fra migrasjonsforskning som kan nyansere bildet. På bakgrunn av dette håper vi å trekke frem noen momenter som kan bidra til at barnehagene både kan ivareta foreldrenes ønsker og Rammeplanens krav.

Ikke alle som tilhører religiøse minoriteter, er migranter. I vår undersøkelse er det imidlertid slik at minoritetsbarna er asylsøkere og flyktninger. Barnehagene har derfor barn fra familier med kort botid i Norge som nylig har vært gjennom en migrasjonsprosess. Dette er typisk for barnehager som mottar barn fra asylmottak, og i distriktskommuner der mange 
flyktninger blir bosatt, men velger å flytte videre etter endt introduksjonsprogram.

Rammeplanen er tydelig på at barnehagen har et spesielt ansvar i forhold til minoritetsforeldrene. Ingen foreldre skal aktivt måtte gå inn og kreve at barnehagen følger Rammeplanens krav, minst av alt minoritetsforeldrene. Tilpasningen til et nytt samfunn skjer ikke på samme måten for alle. Ericsson og Larsen (2000) bruker begrepene «hjemlandsvendt strategi», «norskvendt strategi» og «tolandsvendt strategi» om de forskjellige måtene det er mulig å tilnærme seg det norske samfunnet på. I en «hjemlandsvendt strategi» vektlegges tilknytningen til hjemland og kulturtilhørighet, en «norskvendt strategi» fokuserer på behovet for å legge fortiden bak seg og tilpasse seg det norske samfunnet, mens en «tolandsvendt strategi» tar sikte på å finne en balanse der hjemlandskultur kan opprettholdes samtidig som barna tilpasser seg det norske samfunnet. Berry (1997) har en noe mer kompleks modell, men også han avviser at tilpasningen til et nytt samfunn er lik for alle. Han bruker begrepet akkulturasjon om prosessen som skjer når grupper av mennesker oppvokst innenfor en kulturell kontekst migrerer og kommer i langvarig kontakt med en annen kulturell kontekst. Ifølge Berry velger ulike individer ulike akkulturasjonsstrategier, og disse strategiene kan variere over tid. Strategiene handler om to forhold: kulturelt vedlikehold av opprinnelig kultur og kontakt og deltakelse i storsamfunnet.

En strategi som baserer seg på bevaring av den opprinnelige kulturen og samtidig deltakelse i storsamfunnet, sikter mot integrering. Integrering forstås dermed som en situasjon der minoriteter har lik mulighet til deltakelse i samfunnet som majoritetsbefolkningen, samtidig som elementer fra deres opprinnelseskultur kan opprettholdes. Høytidsmarkering i barnehagen kan sees som en del av det norske samfunnets forsøk på å gi mulighet for integrering i denne forstand, med kulturell ivaretakelse og respekt for mangfold, og like muligheter på samfunnets fellesarenaer.

Assimilering er resultatet av en strategi som tar avstand fra opprinnelig kultur, og søker deltakelse i majoritetskulturen. Separering kan oppstå når strategien tar utgangspunkt i kulturell opprettholdelse og avvisning av storsamfunnet (Fandrem 2011: 71). Akkulturasjonen skjer heller ikke bare på immigrantenes premisser. Integrering kan bare skje dersom storsamfunnet både aksepterer immigrantene som aktive deltakere i samfunnet og aksepterer at ulike kulturer lever side om side. Alternativt tvinges migrantene inn i segregering, assimilering eller marginalisering.

Et utsagn som «Nei, min gutt, han skal være norsk» kan tolkes som uttrykk for en assimilasjonsstrategi. Det er likevel verdt å merke seg at dette bare er én av de tilgjengelige strategiene, og at foreldre som gir uttrykk for dette, ikke representerer alle immigranter, heller ikke alle fra sin egen minoritetsgruppe. Det er ingen grunn til å anta at de foreldrene som aktivt har gitt uttrykk for en assimilasjonsstrategi, representerer de foreldrene som ikke har uttrykt noe eksplisitt rundt dette. I tillegg er det heller ikke sikkert at dette utsagnet representerer foreldrenes holdning gjennom hele akkulturasjonsprosessen. Ifølge Berry vil de fleste immigranter prøve ut ulike strategier, før de etter en stund ender på den de opplever som best. Det er ingen fast rekkefølge på valg av strategi, og det er derfor viktig at de ansatte i barnehagene er klar over at foreldrenes holdninger både til opprinnelseskultur og majoritetssamfunn kan variere over tid.

Sluzki (1979) viser til at perioden rett etter flytting ofte preges av det han kaller 
overkompensasjon ${ }^{9}$. Denne fasen preges av at migrasjonsfamilier den første tiden ofte blir veldig instrumentalistiske i sin tilnærming til den nye kulturen. Valget av tilpasningsstrategier i denne perioden er ifølge Sluzki ofte dårlig tilpasset de langsiktige effektene av migrasjon, noe som i mange tilfeller fører til senere kriser. Effektene av tidlige tilpasningsstrategier kommer gjerne ikke til syne før det har gått flere år etter selve migrasjonen. Sluzkis siste stadium er det han kaller transgenerasjonsfenomener. Her peker han på at effektene av valgte tilpasningsstrategier gir aller størst utslag når det kommer til forholdet mellom generasjonene, spesifikt når barn av migranter vokser opp i det nye samfunnet.

Hensynet til barnets beste skal alltid være utgangspunktet for barnehagens virksomhet. Mye av forskningen som er gjort på integrering og migrasjon, peker på at det er positivt for barnet å få innsikt i og muligheter til å identifisere seg med den kulturbakgrunnen foreldrene har. Portes og Rumbaut (2001) har studert amerikanske innvandrerbarns sosiale mobilitet, og mener at hvorvidt disse lykkes i utdanning og arbeidsliv, spesielt henger sammen med fire faktorer

1) første generasjons innvandringshistorie,

2) hastigheten på tilpasningen til det nye samfunnet hos foreldre og barn,

3) de økonomiske og kulturelle hindringene den oppvoksende generasjon møter i bosettingslandet, og

4) de ressurser som kan mobiliseres i familien og minoritetsgruppen for å overkomme disse hindringene (norsk fremstilling Engebrigtsen og Fuglerud 2009).
Det mest interessante $i$ vår sammenheng er punktene 2 om tilpasningshastighet og 4 om muligheten for støtte i egen etnisk gruppe. Basert på det amerikanske materialet i undersøkelsen deres er det nemlig mye som taler for at tilpasningen til et nytt samfunn ikke bør skje altfor fort for barna, og at det å ha muligheten til å identifisere seg med, og finne støtte i egen etnisk gruppe, er positivt i forhold til mulighetene for å lykkes i er nytt samfunn. Tilpasning som skjer raskere for barna enn de voksne, kaller de «dissonant akkulturasjon». Dette er ifølge dem den minst gunstige formen for akkulturasjon, fordi den bryter ned forholdet mellom foreldre og barn og svekker foreldrenes autoritet. Noe bedre er «konstant akkulturasjon» når foreldre og barn tilpasser seg det nye samfunnet i samme tempo. Likevel er den akkulturasjonsformen Portes og Rumbaut finner mest gunstig «selektiv akkulturasjon», der tilpasningen skjer over lengre tid og uten brudd med egen etnisk gruppe.

Dersom denne forskningen kan overføres på norske forhold, kan det diskuteres om en akkulturasjonsstrategi som bygger på assimilasjon, fremmer barnas interesser.

\section{En flerkulturell barnehage}

Vi finner det uheldig hvis barnehager ikke følger Rammeplanens krav til høytidsmarkering. A markere minoritetsbarns høytider kan være ett av bidragene barnehagen gir for å tilrettelegge en god akkulturasjonsprosess. Det bør være mulig å ivareta Rammeplanens pålegg samtidig som man tar hensyn til personalets usikkerhet og foreldres ønsker. På bakgrunn av intervjuene går det klart frem at det er mest hensiktsmessig å trekke inn ressurspersoner, helst foreldre, men også andre med et forhold til tradisjonene. Det at begge barnehagene har markert id når de

9 Fasene ved migrasjon er a) forberedende stadium; b) migrasjonshandling; c) overkompensasjonsfase; d) dekompensasjonsfase; og e) transgenerasjonsfenomen (Sluzki 1979) (vår oversettelse). 
hadde aktive foreldre og språkassistenter, viser dette med tydelighet.

Som nevnt er mye av forskningen som er gjort knyttet til flerkulturelle barnehager, fokusert på hvordan barnehagene ser på minoritetenes kultur. Vi mener det er nødvendig å nyansere skillet mellom problemfokusert og ressursfokusert perspektiv ytterligere ved å peke på at det ofte kan være et skille mellom perspektiv og praksis. På den måten er det mulig å ha et ressursfokusert perspektiv, men en problemfokusert praksis. Bruker vi dette skillet, står barnehagen vår midt oppe i den situasjonen vi finner beskrevet $i$ en rekke andre undersøkelser, og som kjennetegner institusjoner med problemorientert perspektiv. En barnehagehverdag som er monokulturell i den forstand at minoritetskulturer ikke synliggjøres i det daglige, selv om barnegruppen har sammensatt kulturbakgrunn. Flere har pekt på at for at en barnehage skal kunne kalles flerkulturell, må alle kunne inkluderes i barnehagens fellesskap (Gjervan et al. 2009). I denne sammenhengen blir selve merkelappen «norsk» en utfordring. Ved å stille det å være norskopp mot detåha en annen kulturbakgrunn, noe vi også ser en tendens til i vårt materiale når personalet snakker om «å være norsk $\mathrm{i}$ barnehagen», så lukker vi norskhetsbegrepet inne $\mathrm{i}$ en assimilerende ramme. Idealet $\mathrm{i}$ både lovverket og i integreringslitteraturen er derimot at det er rom for å være norsk også med tilknytning til en minoritetskultur (for eksempel Giæver 2003; Eriksen og Sajjad 2011). En norskhet der både majoritet og minoriteter kan oppleve identitetsbekreftelse. Dette er et større prosjekt enn denne undersøkelsen kan gå inn på, men høytidsmarkeringer er en konkret og nærliggende måte å nærme seg dette på.

En slik endring i praksis krever at barnehagen aktivt jobber for å få innlemmet foreldrene i barnehagens hverdag. Det er flere steder påvist at mange foreldre med minoritetsbakgrunn har vansker med å få klarhet i hva barnehagen forventer og hvordan de kan påvirke barnehagens praksis (Spernes og Hatlem 2013). Her påligger det barnehagene et særlig ansvar for informasjon og arenaer for dialog. Barnehagen kan ikke legge ansvaret for å ta initiativ på foreldrene. Skal vi være helt spesifikke basert på vårt materiale, så trenger barnehagene en dialog med foreldrene som

1) aktivt inviterer foreldrene inn i samarbeid,

2)klargjør hva som menes med høytidsmarkering, særlig med tanke på at det ikke forventes opplegg på selve høytidsdagene da familiene feirer høytidene hjemme, og

3) åpner for at dette er en naturlig del av barnehagens hverdag, ikke noe som skiller seg fra det å være norsk.

Det kan selvsagt være at man fremdeles treffer foreldre som ikke ønsker å markere høytider i barnehagen. Dette kan ikke barnehagene ignorere, men det vil være veldig uheldig om disse ønskene bidrar til at barnehagene helt ser bort fra behovet også minoritetsbarn har for å møte identitetsbekreftelse i barnehagen.

\section{AVSLUTNING}

I denne artikkelen har vi sett på hvordan personalet $i$ to barnehager på Helgeland begrunner at de ikke følger Rammeplanens pålegg om høytidsmarkering. Vi finner at personalet i barnehagene er veldig usikre på hvordan de skal kunne lage gode opplegg knyttet til høytider de ikke selv har noe forhold til. Informantene har også opplevd at minoritetsforeldre ikke ønsker noen markering i barnehagen. Det at barnet skal være norsk, oppgis ofte som grunn.

$\mathrm{Vi}$ argumenterer for at den beste måten 
å ivareta foreldrenes ønsker, barnas beste og lovverkets krav på, er ved å invitere foreldrene sterkere inn i høytidsmarkeringene, og å arbeide med å endre synet på det norske som en selvfølgelig kulturspesifikk bakgrunn som minoritetene ikke er en del av.

Men selv om man klarer å inkludere foreldrene mer, er det fremdeles et stort behov for konkrete opplegg og idéressurser til hvordan man kan markere høytider i praksis. Noen slike ressurser finnes, blant annet hos Geir Winje og hans arbeid med å introdusere det engelske rammeverket «A gift to the child» i forbindelse med høytidsmarkeringer i norske barnehager (Winje 2008; 2010). Vi opplever likevel at behovet er sterkt for videre utviklingsarbeid på dette området.

\section{LITTERATUR}

Andersen, C. E., Engen, T.O., Gitz-Johansen, T., Kristoffersen, C.S., Obel, L.S., Sand, S. og Zachrisen, B. 2011. Den flerkulturelle barnehagen $i$ rurale områder. Nasjonal surveyundersøkelse om minoritetsspråklige barn $i$ barnehager utenfor de store byene. Høgskolen i Hedmark. Rapport nr. 15 2011. Elverum: Høgskolen i Hedmark

Borg, E., Kristiansen, I.-H. og Backe-Hansen, E. 2008 Kvalitet og innhold $i$ norske barnehager. En kunnskapsoversikt. NOVA Rapport 6/2008. Oslo: Norsk institutt for forskning om oppvekst, velferd og aldring.

Berry, J.W. 1997. Immigration, Acculturation, and Adaption, Applied Psychology:.46 s. 5-68

Engebrigtsen, A. I. og Fuglerud, Ø. 2009. Kultur og generasjon. Tilpasningsprosesser blant somaliere og tamiler i Norge. Oslo: Universitetsforlaget

Ericsson, K. og Larsen, G. 2000. Skolebarn og skoleforeldre: om forholdet mellom hjem og skole. Oslo: Pax
Eriksen, T.H. og Sajjad, T.A. 2011. Kulturforskjeller $i$ praksis. 5. utg. Oslo: Gyldendal Akademisk

Fandrem, H. 2011. Mangfold og mestring $i$ barnehage og skole. Migrasjon som risikofaktor og ressurs. Kristiansand: Høyskoleforlaget

Fauske, R. 2012. «Bruken av religiøse forteljingar i barnehagen. Norsk tradisjon og manglande fleirreligiøsitet.» Prismet 63 (1), s. 35-57.

Giæver, K. 2003. «Barnehagen som flerkulturell arena.» i Mørk, O. (red.) «Jeg kjenner ikke han pånorsk, jeg» En artikkelsamling med et flerkulturelt perspektiv. Vallset: Oplandske Bokforlag

Gjervan, M. (Red.) 2006. Temahefte om språklig og kulturelt mangfold. Oslo: Kunnskapsdepartementet

Gjervan, M. 2008. «Foreldre som ressurs for barnehagen - samarbeid om minoritetsspråklige barns språkutvikling» i Aamodt, S. og Hauge, A-M. (red.) Familielcering og andre modeller innenfor flerkulturelt pedagogisk arbeid. Oslo: Universitetsforlaget

Gjervan, M., Andersen og C.E., Bleka, M. 2009. Se mangfold! Perspektiver på flerkulturelt arbeid $i$ barnehagen. Oslo: Cappelen Akademisk forlag

Hauge, A-M. 2014. Den felleskulturelle skolen. 3. utg. Oslo: Universitetsforlaget

Kunnskapsdepartementet 2007. Likeverdig opplaring $i$ praksis. Oslo: Kunnskapsdepartementet

Kunnskapsdepartementet 2011. Rammeplan for barnehagens innhold og oppgaver. Oslo: Kunnskapsdepartementet

Kvale, S. 2001. Det kvalitative forskningsintervju. Oslo: Gyldendal Akademisk

Otterstad, A.M. og Andersen, C.E. 2012. «'Ressursorientert tilnærming til språklig og kulturelt mangfold' Diskursive lesninger 
av inkludering i barnehagen» i Nordisk Barnehageforskning 2012, vol. 5 No. 2 (2) s. 1-21. Oslo: Høgskolen i Oslo og Akershus Portes, A. og Rumbaut, R. 2001. Legacies. The Story of the Immigrant Second Generation. Berkeley: University of California Press

Rosland, K.T, Toft, A. 2013 «Markering av minoriteters høytider i barnehagen: en undersøkelse av forholdet mellom rammeplan og praksis.» i Pareliussen, I., Moen, B.B., Reinertsen, A.B., Solhaug, T. (Red.) FoU i praksis 2012: conference proceedings. Trondheim, 23. og 24. april 2012 s. 216-223, Trondheim: Akademika forlag

Sand, S. 2008. Ulikhet og fellesskap: Flerkulturell pedagogikk i barnehagen. Vallset: Oplandske bokforlag

Sagberg, S. 2001. Autentisitet og undring. En drofting av kristendommens plass $i$ norsk barnehage $i$ institusjonsetisk og personetisk perspektiv. Oslo: Tapir Akademisk Forlag

Sluzki, C.E. (1979). «Migrasjon og familiekonflikt» i Family Process, 18(4), s. 379-390.
Spernes, K. og Hatlem, M. (2013). Den flerkulturelle barnehagen i bevegelse. Teoretiske og praktiske perspektiver. Oslo: Gyldendal Akademisk

Statistisk sentralbyrå 2014 Statistikkbanken. Barnehager [online] tilgjengelig http:// www.ssb.no/tabell/04903 [hentet 29.09.2014]

Sødal, H. K. 2000. Barn med ulik tro. Møte med livssynsmangfoldet $i$ skole og barnehage. Kristiansand: Høyskoleforlaget.

Winje, G. 2008. «Fra divali til halloween» i Moser, T. og Pettersvold, M. (red.) En verden av muligheter - fagområdene $i$ barnehagen. Oslo: Universitetsforlaget

Winje, G. 2010. Høytidsmarkering $i$ barnehagen. En ressursbok. Kristiansand: Høyskoleforlaget

Østrem, S., Bjar, H., Føsker, L. R., Hogsnes, H. D., Jansen, T. T., Nordtømme, S. og Tholin, K. R. 2009. Alle teller mer. En evaluering av hvordan Rammeplan for barnehagens innhold og oppgaver blir innfort, brukt og erfart. Tønsberg: Høgskolen i Vestfold. 